\title{
Isolation, characterization and morphological study of Azotobacter isolates
}

\author{
Sandeep Upadhyay ${ }^{1}$, Narendra Kumar ${ }^{2}$, V. K. Singh ${ }^{3}$ and Anshuman $\operatorname{Singh}^{4}$ \\ ${ }^{1}$ Natural Resource Management Department, Veer Chandra Singh Garhwali College of Horticulture (Uttarakhand \\ University of Horticulture and Forestry) Bharsar, District Pauri- Garhwal- 246123 (Uttarakhand), INDIA \\ ${ }^{2}$ Department of Soil Science, Govind Ballabh Pant University of Agriculture and Technology, Pantnagar, District \\ Udham Singh Nagar -263145 (Uttarakhand), INDIA \\ ${ }^{3}$ Department of Agronomy, Govind Ballabh Pant University of Agriculture and Technology, Pantnagar, District \\ Udham Singh Nagar -263145 (Uttarakhand), INDIA \\ ${ }^{4}$ Krishi Vigyan Kendra (Uttarakhand University of Horticulture and Forestry) Bharsar, District Pauri Garhwal- 246123 \\ (Uttarakhand), INDIA \\ *Corresponding author. E-mail: mistersandeep@gmail.com
}

Received January 18, 2015; Revised received: September 21, 2015; Accepted: November 30, 2015

\begin{abstract}
Among the diazotrops, great attention has been paid to the genus Azotobacter and its role in increasing the growth and health of plants. In the present study, forty two strains of Azotobacter were isolated from soil. These strains were purified and characterized through microscopical and biochemical test for cell shape, pigmentation, colony size, Gram reaction and catalase activity were identified as Azotobacter sp These strains showed wide variability to these characters. Among 42 isolates, 7 were single cocci, 7 coccidal chain and 4 were cocci in clumps. Majority of isolates i.e. 24, were small, medium and large rod shaped. Thirty two isolates were Gram -ve, catalase positive and 10 were Gram +ve, catalase negative. Finally from these isolates, twenty two were confirmed as Azotobacter strains on cyst formation. The carbon-source utilization pattern revealed that out of 22 strains that 16 strains resembled the characters of $A$. chroococcum, 3 matched with $A$. vinelandii and 3 with $A$. beijerinckii. All 22 isolates were analyzed for its nitrogen fixing ability by using Microkjeldhal method. The highest amount of $\mathrm{N}_{2}\left(18.88 \mathrm{mg} \mathrm{g}^{-1}\right.$ sucrose) was fixed by Azo-SBT 72 while lowest $\left(6.04 \mathrm{mg} \mathrm{g}^{-1}\right.$ sucrose) by Azo-SUR 25 strain. However, injudicious and hazardous use of chemical fertilizers have degraded the soil health and there is need of ecofriendly management of soil by screening and hunting of potential nitrogen fixing strains to protect the soil environment and health. In this context, biofertilizers hunting natural environment is the need of soil to ensure better health of future generations.
\end{abstract}

Keywords: Azotobacter isolates, Catalase activity, Cyst formation

\section{INTRODUCTION}

Plant rhizosphere is a very complex niche in which soil, plant and microbe interaction occurs, and plant roots harbours a multitude of different beneficial and deleterious microorganisms. It is due to exudation contains vast organic mix substances such as acids, carbohydrates, nucleic acid derivatives, vitamins, enzymes and other many growth promontory compounds. In this niche, aerobic bacteria belonging to genus Azotobacter play a key role in maintaining soil fertility through several beneficial effects in the rhizosphere of cereals and grasses. In addition to biological nitrogen fixation, production of growth stimulates (IAA, gibberellins, cytokinins), inhibition of phytopathogenic fungi through antifungal substances, Azotobacter maintains a healthy niche for growing plants (Islam et al, 2008).

In hill agriculture, soils have always been rich in biodiversity and prosperous in biomass. In India Uttarakhand is a state where the chemical $\mathrm{N}$ fertilization is completely avoided, and organic farming is still in practice. Isolation and characterization of native strains adapted to local environment is extremely important for several reasons. It may contribute to the formulation of an effective bio-inoculants because indigenous strains of rhizobacteria generally posses more competitive ability to survive and influence the growth of inoculated plants (Khalid et al., 2004). It may also provide a chance to reisolate the soil medium and confirm identity with confidence. The present investigation was conducted for isolation, characterization and morphological study of Azotobacter isolates.

\section{MATERIALS AND METHODS}

Collection and isolation of indigenous Azotobacter isolates: Soil samples were collected during October to December, 2006 in different areas of Almora and U.S. Nagar districts in Kumaun and Tarai regions of Uttarakhand. The samples were collected from rhizospheric soil of different crops (barley, ragi, peas, grass, paddy, amaranth, turmeric and wheat).

For the isolation of different Azotobacter spp. on nitrogen free Jensen's medium, sucrose $10 \mathrm{~g}$, dipotas- 
sium hydrogen phosphate $1 \mathrm{~g}$, magnesium sulphate 0.5 $\mathrm{g}$, sodium chloride $0.5 \mathrm{~g}$, ferrous sulfate $0.1 \mathrm{~g}$, sodium molybdate $0.005 \mathrm{~g}$, agar $20 \mathrm{~g}$, for 1 liter, $\mathrm{pH}$ 7.0-7.2 (Jensen, 1955) was used. Those isolates showing characteristic growth, pigmentation and biochemical reactions of Azotobacter species as described in Bergey's Manual of Systemic Bacteriology (Krieg et al.1994) purified and classified as A. vinelandii, A. chroococcum and A. beijerinckii.

Soil samples were collected by taking out rhizosphere soil of different cereal crops along with plant roots. The soil was carefully removed from the plant roots and kept in fresh plastic bags after labelling and tagging. These samples were preserved in refrigerator at $4{ }^{\circ} \mathrm{C}$ temperature for further use and analyzed for major soil properties as given in Table 1.

The sampled rhizosphere soil was mixed thoroughly to make a composite soil. Then 10 gm of sub-soil sample diluted to $100 \mathrm{ml}$ that considered being $10^{-1}$ dilution factor. Transferring of $1 \mathrm{ml}$ of $10^{-1}$ dilution to $9 \mathrm{ml}$ sterilized water with the help of a sterilized pipettes yielded $10^{-2}$ dilution. In this way, a series of up to $10^{-6}$ dilution was prepared under aseptic condition.

Glassware such as petriplates, pipettes, beakers, conical flasks, test tubes etc. used in the study were sterilized in hot air oven at $160^{\circ} \mathrm{C}$ temperature for at least 2 hours. Similarly, water, medium were sterilized by autoclaving at 15 pounds per square inch $\left(1.05 \mathrm{~kg} \mathrm{~cm}^{-2}\right)$ pressure for 30 minutes.

Plating method: To prepare medium plates, approximately $12-15 \mathrm{ml}$ of sterilized, cool and melted $\left(45^{\circ} \mathrm{C}\right)$ medium was transferred aseptically into petriplates under laminar flow. After solidification of medium, one $\mathrm{ml}$ of suspension from $10^{-4}, 10^{-5}$ and $10^{-6}$ dilutions of each rhizosphere soil sample was poured into each medium plate in triplicate. The plates were incubated at $28 \pm 2{ }^{\circ} \mathrm{C}$ in an incubator in inverted position for $7-10$ days and growth of presumptive Azotobacter was observed on each day during the entire 7 days incubation period. Each well developed colony of Azotobacter which differed in morphology, physical appearance, size ( 3 to $5 \mathrm{~mm}$ in diameter or sometimes even more) and colour was picked up and assumed as a distinct strain.

Later on, the morphological and biochemical characteristics were compared with those defined in Bergey's manual (Krieg et al.1994) to confirm them as Azotobacter strains. The strains with similar characters of Azotobacter were streaked onto another medium plate and were purified by subsequent streaking after each growth till all the colonies in petriplates appeared similar in morphology and characters.

Morphological characterization of Azotobacter isolates: Colony characteristics such as shape, size and appearance of each strain of Azotobacter were recorded as: Cell shape - Oval, rod (small/ medium/ large), oval in chain, rod in chain shaped. Colony shape and size - Raised, flat on the top, domed, coni- cal, regular and irregular. Colour- White, milky white, watery, mucoid and viscous. Consistency- Based on light transmitted through the colony, these were categorized as transparent, translucent and opaque colonies (usually firm with little gum whereas the less dense colonies were often gummy, soft, glistening or dull).

All isolates of Azotobacter were subjected to react with Gram stains as per standard staining procedure described by Cerney (1993).

Diluted bacterial cell suspension was taken with the help of an inoculating loop and it was uniformly spread over in the centre of a clean microscopic slide. The bacterial cells were fixed by heating it through passing repeatedly few seconds over a flame. They were stained with a drop of crystal violet solution (30 seconds), iodine (30 seconds) followed by ethyl alcohol and safranin (1 to 1.5 minutes) solution. After each staining period, the cells were washed under tap water jet and examined under compound microscope using oil immersion lens and these bacterial cells were classified as Gram negative (G-) or gram positive $(\mathrm{G}+)$ or gram variable $(\mathrm{G} \pm)$ strains.

The pigment of all colonies of Azotobacter isolates was noted after a week on a Jensen's agar medium. All isolates of Azotobacter were subjected to react with Violamine stain (Winogradsky, 1949) for $45 \mathrm{sec}$, than washed and counterstained with dilute crystal violet $(0.05 \%)$ for 1 minute. After rinsing with water, the preparation was mounted in water. To investigate the cyst forming ability of Azotobacter and to observe the ultra-structure of Azotobacter cells, electron-microscopy was carried out. Those cells that formed cysts confirmed as Azotobacter and rest those not formed cysts were considered as Azomonas.

The biochemical test was performed as catalase activity test. The test shows the ability of some microbes to degrade hydrogen peroxide by producing the enzyme catalase. Usually,

all Azotobacter species have the capacity to produce oxidases and catalases for the protection of their nitrogenise (Jimenez, et al. 2011). About $1 \mathrm{ml}$ of $3 \%$ of $\mathrm{H}_{2} \mathrm{O}_{2}$ was poured over Azotobacter culture on microscopic slide or in broth. Intensive bubbling (Azotobacter) was noted as catalase positive, slight bubbling was weakly positive; no gas production was catalase negative.

Identification and nomenclature of Azotobacter strains: Each isolated Azotobacter strain was named by suffixing $A z o$ by three alphabetical letters followed by a number as procedure given below in Table 2 . The first letter denotes the first letter of the name of the researcher, middle one denotes the place of its origin, the last letter denotes the rhizospheric crop plant from which it was isolated followed by a number at the end, indicating the strain number which differed with others in cultural/ morphological/ biochemical characteristics. Based on cultural, morphological and biochemical characters all colonies are classified as shown below in Table 3, the confirmation (authenticity) of being genus 
Table 1. Characteristics of sampling sites used for isolation of Azotobacter strains.

\begin{tabular}{|c|c|c|c|c|}
\hline \multirow{3}{*}{ Properties } & \multicolumn{4}{|c|}{ Locations } \\
\hline & \multicolumn{3}{|c|}{ Pantnagar, U.S. Nagar } & \multirow{2}{*}{$\begin{array}{l}\text { Almora } \\
\text { Udaipur }\end{array}$} \\
\hline & Beni & Phoolbagh & *NECRC & \\
\hline Sand $(\%)$ & 8.84 & 38.5 & 42.3 & 33.8 \\
\hline Silt $(\%)$ & 61.41 & 30.8 & 30.0 & 43.4 \\
\hline Clay $(\%)$ & 29.75 & 30.7 & 27.7 & 22.8 \\
\hline Soil texture & Silty clayloam & Clay loam & Clay loam & Loam \\
\hline $\mathrm{pH}$ & 7.30 & 7.10 & 6.15 & 6.88 \\
\hline O.M. (\%) & 1.31 & 1.36 & 1.26 & 1.39 \\
\hline Available $\mathrm{P}_{2} \mathrm{O}_{5}\left(\mathrm{~kg} \mathrm{ha}^{-1}\right)$ & 14.2 & 10.6 & 14.8 & 12.8 \\
\hline Available $\mathrm{K}_{2} \mathrm{O}\left(\mathrm{kg} \mathrm{ha}^{-1}\right)$ & 196 & 188 & 176 & 164 \\
\hline Coordinates & $29^{\circ} 00^{\prime} 56^{\prime \prime} \mathrm{N}$ & $28^{\circ} 01^{\prime} 29^{\prime \prime} \mathrm{N}$ & $29^{\circ} 01^{\prime} 6^{\prime \prime} \mathrm{N}$ & $29^{\circ} 50^{\prime} 53^{\prime \prime} \mathrm{N}$ \\
\hline & $79^{\circ} 30^{\prime} 7.8^{\prime \prime} \mathrm{E}$ & $79^{\circ} 28^{\prime} 20^{\prime \prime} \mathrm{E}$ & $79^{\circ} 28^{\prime} 40^{\prime \prime} \mathrm{E}$ & $79^{\circ} 11^{\prime} 37^{\prime \prime} \mathrm{E}$ \\
\hline
\end{tabular}

*NECRC $=$ Norman E. Borlog Crop Research Centre, Pantnagar, U.S. Nagar

Table 2. Nomenclature of isolated Azotobacter strains.

\begin{tabular}{lllll}
\hline S.N. & Sampling site & Rhizosphere & $\begin{array}{l}\text { Strain } \\
\text { name }\end{array}$ & $\begin{array}{l}\text { Symbols of presumptive Azotobacter } \\
\text { strains }\end{array}$ \\
\hline 1 & Beni, Pantnagar (B) & Barley (B) & *SBB & SBB 1 \\
2 & Udaipur, Almora (U) & Ragi (R) & SUR & SUR 2, SUR 21, SUR 22, SUR 23 etc. \\
3 & Phoolbag, Pantnagar (P) & Peas (P) & SPP & SPP 3, SPP 31, SPP 32 \\
4 & Phoolbag, Pantnagar (P) & Grass (G) & SPG & SPG 4, SPG 41, SPG 42 \\
5 & CRC, Pantnagar (C) & Rice (R) & SCR & SCR 5, SCR 51, SCR 52 etc \\
6 & Udaipur, Almora (U) & Amaranth (A) & SUA & SUA 61, SUA 62, SUA 63 etc. \\
7 & Beni, Pantnagar (B) & Turmeric (T) & SBT & SBT 7, SBT 71, SBT 72 etc. \\
8 & Udaipur, Almora (U) & Wheat (W) & SUW & SUW 8, SUW 81, SUW 83 etc. \\
\hline
\end{tabular}

$* \mathrm{~S}=$ Sandeep $(*$ Initial letter $=$ Name of the researcher $) ; \mathrm{B}=$ Beni; $\mathrm{B}=$ Barley crop $($ collectively $\mathrm{SBB})$

Azotobacter had been made as per the description given in Bergey's Manual of Systemic Bacteriology (Holt and Krieg, 1984). Aquilanti et al. (2004) described different strategies to isolate Azotobacter from soil samples. He concluded that soil pasteplate method combined with isolation of mannitol agar proved to be the best strategy in terms of reliability and selectivity.

Determination of dinitrogen fixing capacity: The nitrogen fixing efficacy of each strain was determined in terms of the amount of total nitrogen fixed in $25 \mathrm{ml}$ broth culture in 7 days under bacteriological controlled conditions shown below in Table 5. Jensen's broth containing all the ingredients, except agar was prepared in Jensen (1955). After pouring $25 \mathrm{ml}$ broth in each $150 \mathrm{ml}$ conical flask and plugging with cotton wool, the flasks were autoclaved. After cooling, each flask was inoculated by adding $0.1 \mathrm{ml}$ broth culture of the each strain in triplicate and the flasks were shaken on a rotary shaker for 7 days at $28 \pm 2{ }^{\circ} \mathrm{C}$. From each flask, $5 \mathrm{ml}$ broth culture was used to determine the total nitrogen by the microkjeldahl method as described by Jackson (1967). Further, the population of Azotobacter in each broth culture was determined by serial dilution pour plate method.

The total number of Azotobacter cells per gram soil was calculated by multiplying the average number of colonies with $10^{5}$ as dilution factor, using the following formula.

No. of Azotobacter cells in broth culture (c.f.u.ml ${ }^{-1}$ ) $=$ No. of colonies plate ${ }^{-1} \times$ dilution factor

\section{RESULTS AND DISCUSSION}

\section{Characterization of Azotobacter isolates}

Cell / colony shape and size: The morphological characters of Azotobacter isolates revealed that cells of Azotobacter isolates namely Azo-SUR 2, Azo-SPP 3, Azo-SUA 63, Azo-SUA 68, Azo-SUA 69, Azo-SUW 83, Azo-SUW 84 were cocci in single, while the cells of Azo SUR 21, Azo-SPG 4, Azo-SCR 5, Azo-SCR 51, $A z o-S C R$ 53, Azo-SUA 66, Azo-SUA 67 were cocci in chains and cells of Azotobacter isolates Azo-SPG 41, $A z o$-SCR 54, Azo-SCR 56, and Azo-SBT 74 were cocci in clumps.

Remaining other strains, Azo-SBB 1, Azo-SUA 6, AzoSUA 62, Azo-SUA 64 were single rods, while AzoSUR 22, Azo-SPP 31, Azo-SPG 42, Azo-SCR 55, AzoSUA 61, $A z o$-SUA 65, $A z o$-SUW 8, were rods in chain. The cells of Azo-SUR 25, Azo-SPP 32 were small rods. The cells of $A z o$-SUR 23, Azo-SUR 26, Azo -SPP 33, Azo-SCR 52, Azo-SBT 7, Azo-SBT 72, AzoSBT 73 isolates were medium rods, however, long rods were observed in Azo-SUR 24, Azo-SBT 71, AzoSUW 81 and $A z o$-SUW 82 isolates. The morphological characters of Azotobacter isolates showed that among 42 isolates, 7 were single cocci, 7 coccidal chain and 4 were cocci in clumps. Majority of isolates i.e. 24, were small, medium and large rod shaped/bacilli (Table 3).

The colonies developed on Jensen's agar medium were raised, spherical flat and few with irregular margins. The colony size varied from $\geq 2 \mathrm{~mm}$ to $\geq 5 \mathrm{~mm}$ in 7 days. It is evident that Azotobacter isolates were pleo- 
Table 3: Morphological and cultural characteristics of isolated Azotobacter strains (Colony characteristics one week after streaking).

\begin{tabular}{|c|c|c|c|c|c|c|c|c|}
\hline S. N. & Azotobacter name & Cell shape & $\begin{array}{c}\text { Colony shape / } \\
\text { margin }\end{array}$ & $\begin{array}{c}\text { Size } \\
(\mathbf{m m})\end{array}$ & Colour & Consistency & $\begin{array}{c}\text { Gram } \\
\text { staining }\end{array}$ & $\begin{array}{c}\text { Catalase } \\
\text { test }\end{array}$ \\
\hline 1 & $A z o-\mathrm{SBB} 1$ & Rod singly & Spherical, punctiform & 2.8 & Dull white & Slimy & - & + \\
\hline 2 & Azo-SUR 2 & Oval & Spherical, flat & 3.8 & Dull white & Mucoid & - & + \\
\hline 3 & Azo-SUR 21 & Oval in chains & Circular, smooth & 3.0 & $\begin{array}{l}\text { Dull white to } \\
\text { brownish Clear }\end{array}$ & Viscous & - & + \\
\hline 4 & Azo-SUR 22 & Rod in chains & Circular, raised & 4.2 & Clear white & Milky & - & + \\
\hline 5 & Azo-SUR 23 & Medium rod & Circular, raised & 4.2 & Pale yellow & Mucoid & - & + \\
\hline 6 & Azo-SUR 24 & Large rod & $\begin{array}{l}\text { Circular, smooth, } \\
\text { pulvinate }\end{array}$ & 5.6 & Dull white & Viscous & - & + \\
\hline 7 & Azo-SUR 25 & Small rod & Rhizoid, flat & 2.8 & $\begin{array}{c}\text { Creamy white, } \\
\text { off-white }\end{array}$ & Dry-Diffused & + & - \\
\hline 8 & Azo-SUR 26 & Medium rod & Spherical, convex & 5.0 & $\begin{array}{l}\text { White to light } \\
\text { yellow }\end{array}$ & Slimy & - & + \\
\hline 9 & Azo-SPP 3 & Spherical & $\begin{array}{l}\text { Large, slimy, glisten- } \\
\text { ing }\end{array}$ & 3.0 & Dull white & $\begin{array}{l}\text { Glistening, } \\
\text { Gummy }\end{array}$ & - & + \\
\hline 10 & Azo-SPP 31 & Rod in chains & $\begin{array}{l}\text { Smooth, circular } \\
\text { and highly convex }\end{array}$ & 2.5 & $\begin{array}{l}\text { Dull white to } \\
\text { yellowish }\end{array}$ & $\begin{array}{c}\text { Mucoid, } \\
\text { viscid }\end{array}$ & - & + \\
\hline 11 & Azo-SPP 32 & Small rod & Irregular, large & 2.8 & $\begin{array}{l}\text { Un-pigmented to } \\
\text { whitish }\end{array}$ & Slimy & - & + \\
\hline 12 & Azo-SPP 33 & Medium rod & Rhizoid, flat & 2.9 & Clear & Dry & - & + \\
\hline 13 & Azo-SPG 4 & Cocci in chains & Filamentous & 2.9 & Pale yellow & Dry & - & + \\
\hline 14 & Azo-SPG 41 & Cocci in clumps & Circular smooth & 3.0 & Pale yellow & Dry & - & + \\
\hline 15 & Azo-SPG 42 & Rod in chains & Circular, flat margin & 3.2 & White & Weak slimy & - & + \\
\hline 16 & Azo-SCR 5 & Cocci in chains & $\begin{array}{l}\text { Rhizoid Irregular, } \\
\text { radiate }\end{array}$ & 2.8 & Pale yellow & Dry & + & - \\
\hline 17 & Azo-SCR 51 & Cocci in chains & Spherical, flat & 2.9 & Dull white & Milky & + & - \\
\hline 18 & Azo-SCR 52 & Cocci in clumps & $\begin{array}{l}\text { Slimy, circular and } \\
\text { convex }\end{array}$ & 2.8 & $\begin{array}{l}\text { Pale yellow to } \\
\text { Brown }\end{array}$ & Milky & - & + \\
\hline 19 & Azo-SCR 53 & Cocci in chains & $\begin{array}{l}\text { Slimy, circular, con- } \\
\text { vex }\end{array}$ & 2.0 & $\begin{array}{l}\text { White to yellow } \\
\text { brown }\end{array}$ & Milky & - & + \\
\hline 20 & Azo-SCR 54 & Cocci in clumps & Entire, circular, raised & 2.3 & Dull white to brown & Viscous & - & + \\
\hline 21 & Azo-SCR 55 & Rods in chains & Radiate, raised & 2.3 & $\begin{array}{l}\text { Creamy white to } \\
\text { brown }\end{array}$ & Slimy & - & + \\
\hline 22 & Azo-SCR 56 & Cocci in clumps & Poor growth & 2.8 & $\begin{array}{l}\text { White to black } \\
\text { brown }\end{array}$ & Viscous & + & - \\
\hline 23 & Azo-SUA 6 & Rod singly & Poor growth & 3.0 & Yellowish to white & Viscous & + & - \\
\hline 24 & Azo-SUA 61 & Rods in chains & $\begin{array}{l}\text { Slimy, circular and } \\
\text { convex }\end{array}$ & 3.3 & Clear translucent & Mucoid & + & - \\
\hline 25 & Azo-SUA 62 & Rods singly & Spherical, Punctiform & 2.8 & Yellowish to brown & Milky & - & + \\
\hline 26 & Azo-SUA 63 & Cocci singly & $\begin{array}{l}\text { Slimy, circular and } \\
\text { convex }\end{array}$ & 3.5 & Dull white & Viscous & - & + \\
\hline 27 & Azo-SUA 64 & Rods singly & Spreading, convex & 4.5 & Brownish & Viscous & - & + \\
\hline 28 & Azo-SUA 65 & Rods in chains & $\begin{array}{c}\text { Circular, contoured, } \\
\text { convex }\end{array}$ & 3.0 & Yellowish white & Mucoid & - & + \\
\hline 29 & Azo-SUA 66 & Cocci in chains & $\begin{array}{l}\text { Spherical, Punctiform } \\
\text { margin }\end{array}$ & 3.0 & Yellowish to white & Viscous & - & + \\
\hline 30 & Azo-SUA 67 & Cocci in chains & Poor growth & 2.5 & Yellowish to white & Dry & + & - \\
\hline 31 & Azo-SUA 68 & Cocci single & Poor growth & 2.8 & Yellowish & Dry & + & - \\
\hline 32 & Azo-SUA 69 & Cocci single & Poor growth & 2.0 & Clear & Dry & + & - \\
\hline 33 & Azo-SBT 7 & Medium rod & $\begin{array}{l}\text { Slimy, circular } \\
\text { and convex }\end{array}$ & 4.2 & Yellowish to white & Viscous & - & + \\
\hline 34 & Azo-SBT 71 & Large single rod & $\begin{array}{l}\text { Entire, convex and } \\
\text { spreading }\end{array}$ & 5.6 & Brown & Viscous & - & + \\
\hline 35 & Azo-SBT 72 & Medium rod & $\begin{array}{l}\text { Slimy, circular and } \\
\text { convex }\end{array}$ & 4.0 & Brownish black & Milky & - & + \\
\hline 36 & Azo-SBT 73 & Medium rod & $\begin{array}{l}\text { Slimy, circular and } \\
\text { convex }\end{array}$ & 4.5 & $\begin{array}{l}\text { Dull white to } \\
\text { brownish black }\end{array}$ & Slimy & - & + \\
\hline 37 & Azo-SBT 74 & Cocci in clumps & Poor growth & 3.3 & Clear & Milky & + & - \\
\hline 38 & Azo-SUW 8 & Rods in chains & $\begin{array}{l}\text { Slimy, circular and } \\
\text { convex }\end{array}$ & 4.2 & $\begin{array}{l}\text { White to brownish } \\
\text { black }\end{array}$ & Milky & - & + \\
\hline 39 & Azo-SUW 81 & Large rods & Circular, wrinkled & 4.5 & Creamy white & Gummy & - & + \\
\hline 40 & Azo-SUW 82 & Large rods & Spreading, convex & 4.0 & $\begin{array}{l}\text { Yellowish brown- } \\
\text { black }\end{array}$ & Mucoid & - & + \\
\hline 41 & Azo-SUW 83 & Cocci single & Spherical, punctiform & 3.6 & Dull Brown & Viscous & - & + \\
\hline 42 & Azo-SUW 84 & Cocci single & Wrinkled, raised & 3.2 & Clear & Milky & - & + \\
\hline
\end{tabular}


Table 4: Discrimination of Azotobacter isolates characters for classification into different species.

\begin{tabular}{|c|c|c|c|c|c|c|c|}
\hline \multirow{2}{*}{ S. N. } & \multirow{2}{*}{$\begin{array}{l}\text { Azotobacter } \\
\text { strains }\end{array}$} & \multicolumn{3}{|c|}{ Carbon source utilized } & \multirow{2}{*}{ Cyst } & \multirow{2}{*}{$\begin{array}{l}\text { Extracellular } \\
\text { polysaccharide } \\
\text { production }\end{array}$} & \multirow{2}{*}{ Result } \\
\hline & & Starch & Maltose & Rhamnose & & & \\
\hline 1 & $A z o-$ SUR 2 & - & - & - & + & + & A. beijerinckii \\
\hline 2 & Azo-SUR 21 & - & - & - & + & + & A. beijerinckii \\
\hline 3 & Azo-SUR 22 & + & + & - & + & + & A. chroococcum \\
\hline 4 & Azo-SUR 23 & + & + & - & + & + & A. chroococcum \\
\hline 5 & Azo-SUR 24 & + & + & - & + & + & A. chroococcum \\
\hline 6 & Azo-SUR 25 & + & + & - & + & + & A. chroococcum \\
\hline 7 & Azo-SUR 26 & + & + & - & + & + & A. chroococcum \\
\hline 8 & Azo-SPP 3 & + & + & - & + & + & A. chroococcum \\
\hline 9 & Azo-SPP 31 & + & + & - & + & + & A. chroococcum \\
\hline 10 & Azo-SPG 42 & + & + & - & + & + & A. chroococcum \\
\hline 11 & Azo-SCR 52 & - & + & + & + & + & A. vinelandii \\
\hline 12 & Azo-SCR 53 & + & + & - & + & + & A. chroococcum \\
\hline 13 & Azo-SCR 55 & + & + & - & + & + & A. chroococcum \\
\hline 14 & Azo-SUA 61 & + & + & - & $\begin{array}{l}T \\
+\end{array}$ & + & A. chroococcum \\
\hline 15 & Azo-SUA 63 & + & + & - & + & + & A. chroococcum \\
\hline 16 & Azo-SUA 65 & + & + & - & + & + & A. chroococcum \\
\hline 17 & Azo-SBT 7 & - & + & + & + & + & A. vinelandii \\
\hline 18 & Azo-SBT 71 & - & + & + & + & + & A. vinelandii \\
\hline 19 & Azo-SBT 72 & + & + & - & + & + & A. chroococcum \\
\hline 20 & Azo-SBT 73 & + & + & - & + & + & A. chroococcum \\
\hline 21 & Azo-SUW 8 & + & + & - & + & + & A. chroococcum \\
\hline 22 & Azo-SUW 82 & - & - & - & + & + & A. beijerinckii \\
\hline
\end{tabular}

morphic in nature. The variation in cell shape, colony size and its appearance was because of various factors such as presence of disorganized, shapeless massessymplasms, giant spindle shaped cells branched form and even spore formation in cultures of Azotobacter (Pleomorphism) may also be attributed to the composition of the medium and the stage of its growth in the medium as has been reported by Aquilanti et al. (2004). The colony characters such as colony-margin, size, colour and consistency also differed among different isolates of Azotobacter (Table 4). Thirty two isolates were Gram -ve and 10 were Gram +ve, hence were not Azotobacter isolates. It is in agreement with the obtained results by (Tejera, et al. 2005; Ahmad, et al. 2008).

Gram staining test, catalase activity test: Thirty one Azotobacter isolates were found catalase positive while 11 isolates were catalase negative (Table 4) hence were not Azotobacter. The isolates of Azotobacter were studied for their carbon source utilization and cyst forming behaviour to confirm and differentiate them into different species according to the Bergey's Manual of Systematic Bacteriology (Table 4). Thirty one isolates showed catalase positive test and eleven catalase negative.

Colony colour and consistency: Different Azotobacter isolates showed wide variability in consistency and colony colour. Isolates were reported unevenness in colour and flowing consistency mucoid, viscous, milky, glistening, gummy with dull to cream white, pale yellow, brown as described by John et al. (1994). Azo-SBT 7, Azo-SBT 72, Azo-SBT 73 isolates were medium rods, however, long rods were observed in Azo-SUR 24, Azo-SBT 71, Azo-SUW 81 and AzoSUW 82 isolates.

Carbon source utilization and cyst behaviour: It is evident from the carbon source utilization behaviour of 22 strains that 16 strains resembled the characters of $A$. chroococcum, 3 matched with $A$. vinelandii and 3 with A. beijerinckii. This confers the reports that $A$. chroococcum is the most commonly encountered species among the genus Azotobacter (Voets and Dedeken, 1966) also survival of $A$. chroococcum in Nainital tarai as reported by Banerjee (1977).

The most important character of Azotobacter is its ability to fix atmospheric nitrogen by the enzyme popularly known as nitrogenase. The nitrogen fixation by Azotobacter has been reported from $2-15 \mathrm{mg} \mathrm{N} \mathrm{g}^{-1}$ of carbon utilized (Becking, 1992). however Ravikumar et al. (2004), Stella and Suhaimi (2010) also reported these three species of Azotobacter, A. chroococcum, A. vinelandii and $A$. beijerinckii, exhibited high growth, nitrogen fixation and in vitro production of phytohormone.

Azotobacter population and their $\mathbf{N}_{2}$-fixing efficiency in broth: The viable counts of all 22 Azotobacter strains varied from $23-89 \times 10^{6}$ c.f.u. $\mathrm{ml}^{-1}$ broth. Highest population of $89.32 \times 10^{6}$ c.f.u. $\mathrm{ml}^{-1}$ broth was recorded with strain $A z o$-SUR 23, however, strains $A z o$ -SBT 7, Azo-SBT 72, Azo-SBT 73 and Azo-SUW 82 were at par with strain $A z o-S U R$ 23. The minimum number of cells $23 \times 10^{6}$ c.f.u. $\mathrm{ml}^{-1}$ broth was recorded in Azo-SUA 61 strain.

The amount of $\mathrm{N}_{2}$ fixed by different strains ranged 
Table 5. Population of Azotobacter strains in broth and amount of $\mathrm{N}_{2}$ fixed by them.

\begin{tabular}{|c|c|c|c|}
\hline S. $\mathbf{N}$. & $\begin{array}{l}\text { Azotobacter } \\
\text { Strains }\end{array}$ & $\begin{array}{l}\text { Population } \\
\left(\times 10^{6} \text { c.f.u. }\right. \\
\left.\mathrm{ml}^{-1}\right) \\
\end{array}$ & $\begin{array}{l}\mathrm{N}_{2} \text { Fixed } \\
\left(\mathrm{mg} \mathrm{g}^{-1}\right. \\
\text { Sucrose })\end{array}$ \\
\hline 1 & Control & -- & -- \\
\hline 2 & Azo-SUR 2 & 62.33 & 11.04 \\
\hline 3 & Azo-SUR 21 & 66.05 & 17.40 \\
\hline 4 & Azo-SUR 22 & 70.93 & 9.09 \\
\hline 5 & Azo-SUR 23 & 89.32 & 12.08 \\
\hline 6 & Azo-SUR 24 & 39.71 & 7.00 \\
\hline 7 & Azo-SUR 25 & 45.35 & 6.04 \\
\hline 8 & Azo-SUR 26 & 58.99 & 9.21 \\
\hline 9 & Azo-SPP 3 & 55.35 & 9.80 \\
\hline 10 & Azo-SPP 31 & 28.08 & 10.34 \\
\hline 11 & Azo-SPG 42 & 69.80 & 10.10 \\
\hline 12 & Azo-SCR 52 & 56.97 & 12.34 \\
\hline 13 & Azo-SCR 53 & 65.45 & 11.44 \\
\hline 14 & Azo-SCR 55 & 24.08 & 10.72 \\
\hline 15 & Azo-SUA 61 & 23.00 & 6.12 \\
\hline 16 & Azo-SUA 63 & 35.81 & 13.28 \\
\hline 17 & Azo-SUA 65 & 44.75 & 16.23 \\
\hline 18 & Azo-SBT 7 & 83.38 & 10.42 \\
\hline 19 & Azo-SBT 71 & 66.16 & 16.85 \\
\hline 20 & Azo-SBT 72 & 83.92 & 18.88 \\
\hline 21 & Azo-SBT 73 & 87.75 & 16.92 \\
\hline 22 & Azo-SUW 8 & 72.66 & 9.66 \\
\hline \multirow[t]{4}{*}{23} & Azo-SUW 82 & 85.32 & 18.42 \\
\hline & SEm \pm & 2.98 & 1.29 \\
\hline & $\mathrm{CD}$ at $5 \%$ & 8.50 & 3.62 \\
\hline & $\mathrm{CV}$ & 8.63 & 4.48 \\
\hline
\end{tabular}

from 6.04 to $18.88 \mathrm{mg} \mathrm{g}^{-1}$ sucrose. Highest amount of nitrogen was fixed by $A z o-S B T 72$ while lowest by Azo-SUR 25. The strains namely Azo-SUR 21, AzoSUA 65, Azo-SBT 71, Azo-SBT 73 and Azo-SUW 82 did not differ significantly from $A z o$-SBT 72 . Other strains fixed significantly lower nitrogen than Azo-SBT 72. The strain $A z o$-SBT 72 had 3.12 fold $\mathrm{N}_{2}$ fixation power over Azo-SUR 25. All the Azotobacter strains fixed significantly more $\mathrm{N}_{2}$ except Azo-SUR 22, AzoSUR 24, Azo-SUR 26, Azo-SUA 61 and Azo-SUW 8 than $A z o$-SUR 25 and $A z o$-SPP 3 . Yoshida (1972) also reported that biological nitrogen fixation in Philippine rice fields were ranged from 2.30 to $33.3 \mathrm{~kg} \mathrm{ha}^{-1}$. Similarly results were obtained by Narayan and Kehri (2011) studying effect of different agricultural practices on population dynamics of Azotobacter chroococcum and its nitrogen fixing potentiality in Trans-Ganga and Trans-Yamuna plains of India.

All the Azotobacter strains differed in their viable counts in broth culture. The number of cells depends upon the generation time and physiological characteristics of the strains, therefore, the population varied in the broth. This is well known fact in conformity with Brock et al. (1994). The $\mathrm{N}_{2}$ fixing capacity of Azotobacter strains also differed from strain to strain. The fixation of $\mathrm{N}_{2}$ depends upon the activation of nitrogenase enzyme, which may vary from strain to strain. The wide variations in nitrogen fixing capacity of different strains of Azotobacter have also been reported by Sanoria and Sundara Rao (1975), Mahmoud et al. (1978) and Tippannavar and Reddy (1987). These isolation results have close conformity with findings of Torres, et al. (2000). They obtained Azotobacter chroococcum, A. vinelandii, Pseudomonas aeruginosa and Klebsiella pneumonia strains from rhizosphere of rice cultivated in the Tolima region,

\section{Conclusion}

Based on the performed study of isolation, characterization of Azotobacter it was found that some Azotobacter species namely $A$. chroococcum, A. vinelandii and $A$. beijerinckii were well distributed in crop growing soils of Tarai and Kumaun region. The bacteria showed Gram negative, catalase positive, cyst forming nature though, pleomorphism in shape. On carbon source utilization behaviour, Azotobacter showed its species variation as out of 22 strains that 16 strains confirmed the characters of $A$. chroococcum, 3 matched with $A$. vinelandii and 3 with $A$. beijerinckii. Among these isolates peak amount of $\mathrm{N}_{2}$ fixed was $18.88 \mathrm{mg} \mathrm{g}^{-1}$ sucrose by a strain Azo-SBT 72. Therefore, the genus Azotobacter was active in the maintenance of soil fertility and productivity of local farms. Isolation, purification and screening out highly efficient Azotobacter strains from natural field showed potentiality to find out better inoculants preparation for further research trials.

\section{REFERENCES}

Ahmad, F, Ahmad, I. and Khan, M.S. (2008). Screening of free-living rhizospheric bacteria for their multiple plant growth promoting activities. J. Microbiol. Research. 163: 173-181.

Aquilanti, L., Favilli, F. and Clementi, F. (2004). Comparison of different strategies for isolation and preliminary identification of Azotobacter from soil samples. Soil Biol. Biochem., 36: 1475-1483.

Banerjee, S. (1977). Morphological and physiological characteristics of different strains of Azotobacter isolated from soils of Nainital tarai. Pantnagar J. Res., 2(2): 262.

Becking, J.H. (1992). The family Azobacteraceae, $2^{\text {nd }}$ ed, Springer, Verlag, Berlin, pp. 3144-3170.

Brock, T.D., Madigan, T.M., Martinko, J.M. and Parker, J. (1994). Biology of Microorganisms. $7^{\text {th }}$ ed. Prentice Hall International, Inc., USA. p. 142.

Cerney, G. (1993). Method for the distinction of gram negative and gram positive bacteria. EU J. Appl Micro. (3), 223-225.

Holt, J.G. and Krieg, N.R. (ed.) (1984). Bergey's Manual of Systematic Bacteriology, vol. 1. Wiliams and Wilkins, Baltimore, Md, pp 219.

Islam, M.Z., Sharif, D.I. and Hossain, M.A. (2008). A comparative study of Azotobacter spp. from different soil samples. J. Soil Nature. 2(3): 16-19.

Jackson, M.L. (1967). Soil chemical analysis. Prentice Hall of India Pvt. Ltd., New Delhi. pp. 263-293.

Jensen, H.L. (1955). Non-symbiotic nitrogen fixation In: Soil nitrogen (eds.) Barthdlomew, W.V. and Clark, F. E. American Soc. Agron. Inc. Madison, 10: 436-480. 
Jimenez, J.D., Montana, J.S., Martínez, M.M. (2011). Characterization of free nitrogen fixing bacteria of the genus Azotobacter in organic vegetable-grown Colombian soils. Braz. J. Microbiol. 42(3) 66-78.

John, G.H., Noel, R.K., Peter, H.A.S., James, T.S. and Stanley, T.W. (1994). Aerobic/ microaerophilic, motile, helical/vibroid Gram negative bacteria. In: Bergey's Manual of Determinative Bacteriology. p. 39-45. USA: Lippincott Williams \& Wilkins.

Khalid, A., Arshad, M. and Zaheer, Z.A. (2004). Screening plant promoting rhizobacteria for improving growth and yield of wheat. J. Appl. Microbiol., 96: 473-480.

Krieg N.R., Holt J.G., Sneath P.H.A., Staley J.T., and Williams S.T. (1994). Bergey's Manual of Determinative Bacteriology ( $9^{\text {th }}$ ed.), Williams \& Wilkins, Baltimore, Md, USA.

Mahmoud, S.A.Z., El-Sawy, M., Ishac, Y.Z. and El-Safty, M.M. (1978). The effects of salinity and alkalinity on the distribution and capacity of $\mathrm{N}_{2}$ fixation by Azotobacter in Egyptian soils. Ecol. Bull. NFR (Naturvetensk. Forskningsradet) 26: 99-109.

Narayan, R.P. and Kehri, H.K. (2011). Effect of different agricultural practices on population dynamics of Azotobacter chroococcum and its nitrogen fixing potentiality in Trans- Ganga and Trans-Yamuna plains of India. Acta Agriculture Serbia, 16.97-122.

Ravikumar, S., Kathiresan, K., Ignatiammal, S.T.M., Selvam, M.B. and Shanty, S. (2004). Nitrogen-fixing azotobacters from mangrove habitat and their utility as marine biofertilizers. Journal of Experimental Marine Biology and Ecology 312: 5-17.
Sanoria, C.L. and Sundara Rao, W.V.B. (1975). Effect of seed bacterization with Azotobacter chroococcum on sorghum and wheat. Indian J. Agric. Sci. 45: 224-226.

Stella, M. and Suhaimi, M. (2010). Selection of suitable growth medium for free-living diazotrophs isolated from compost. J. Trop. Agric. and Fd. Sc. 38(2): 211219.

Tejera, N., Luch, C., Martinez-Toledo, M.V., Gonzalez-Lopez, J. (2005). Isolation and characterization of Azotobacter and Azospirillumstrains fromsugarcane rhizosphere. J. Plant and Soil: 223-232.

Tippannavar, C.M. and Reddy, T.K.R. (1987). Population dynamics of Azotobacter in different soil types, their nitrogen fixing capacities and effect of Azotobacter isolates on wheat seed germination. J. Farm. Sys. 3(34): 67-71.

Torres-Rubio, M.G., Valencia-Plata, S.A., Bernal-Castillo J. and Martienez-Nieto, P. (2000). Isolation of Enterobacteria, Azotobacter sp. and Pseudomonas sp., Producers of Indole-3-Acetic Acid and Siderophores from Colombian Rice Rhizosphere. R.L. De Microbiologiea, 42: 171-176.

Voets, J.P. and Dedeken, M. (1966). A physiological approach to the classification of the genus Azotobacter (c.f.) The biological fixation of atmospheric nitrogen by free living bacteria. In : "Soil Biology: Review of Research". Nat. Resour. Res. UNESCO, 9: 65-125.

Winogradsky, S.N. (1949). Microbiologie du soil problems et methods (e.f.). The Azotobacteraceae. In: Bacterial Review. 18: 199. 